\title{
Detection of three Allexivirus species infecting garlic in Brazil
}

\author{
Péricles de Albuquerque Melo Filho( ${ }^{(1)}$, Tatsuya Nagata(2), André Nepomuceno Dusi( ${ }^{(3)}$, José Amauri Buso ${ }^{(3)}$, \\ Antonio Carlos Torres ${ }^{(3)}$, Marcelo Eiras ${ }^{(4)}$ and Renato de Oliveira Resende ${ }^{(5)}$
}

\begin{abstract}
(1)Universidade Federal Rural de Pernambuco, Dep. de Agronomia, CEP 52171-900 Recife, PE. E-mail: pericles@ufrpe.br (2)Universidade Católica de Brasília, SGAN 916, Módulo B, CEP 70790-160 Brasília, DF. E-mail: tatsuya@pos.ucb.br (3)Embrapa Hortaliças, Caixa Postal 218, CEP 70359-970 Brasília, DF. E-mail: dusi@cnph.embrapa.br, buso@cnph.embrapa.br (4)Instituto Biológico, Centro de Pesquisa e Desenvolvimento de Sanidade Vegetal, CEP 04014-202 São Paulo, SP. E-mail: eiras@biologico.br (5)Universidade de Brasília, Dep. de Biologia Celular, CEP 70919-970 Brasília, DF. E-mail: resende@unb.br
\end{abstract}

\begin{abstract}
Garlic viruses often occur in mixed infections under field conditions. In this study, garlic samples collected in three geographical areas of Brazil were tested by Dot-ELISA for the detection of allexiviruses using monoclonal specific antibodies to detect Garlic virus A (GarV-A), Garlic virus B (GarV-B), Garlic virus C (GarV-C) and a polyclonal antiserum able to detect the three virus species mentioned plus Garlic virus D (GarV-D). The detected viruses were biologically isolated by successive passages through Chenopodium quinoa. Reverse Transcriptase Polimerase Chain Reaction (RT-PCR) was performed using primers designed from specific regions of the coat protein genes of Japanese allexiviruses available in the Genetic Bank of National Center of Biotechnology Information (NCBI). By these procedures, individual garlic virus genomes were isolated and sequenced. The nucleotide and amino acid sequence analysis and the one with serological data revealed the presence of three distinct allexiviruses GarV-C, GarV-D and a recently described allexivirus, named Garlic mite-borne filamentous virus (GarMbFV), in Brazil.
\end{abstract}

Index terms: Allium sativum, virus detection, coat protein, Dot-ELISA, RT-PCR.

\section{Detecção de três espécies de Allexivirus que infectam o alho no Brasil}

\begin{abstract}
Resumo - Infecções virais em alho são normalmente causadas por um complexo viral. Neste estudo, um complexo viral de alho, coletado em campo, em três regiões geográficas, foi testado com anti-soros monoclonais específicos para Garlic virus A (GarV-A), Garlic virus B (GarV-B), Garlic virus C (GarV-C) e um anti-soro policlonal capaz de detectar os três vírus mencionados e Garlic virus $D$ (GarV-D). Procedeu-se à amplificação por transcriptase reversa-reação em cadeia da polimerase (RT-PCR) usando oligonucleotídeos sintetizados a partir de regiões específicas de genes de proteínas capsidiais de allexivirus japoneses e disponíveis no GeneBank (National Center of Biotechnology Information - NCBI). Por esse procedimento, vírus individuais foram isolados e sequienciados. Os vírus detectados foram biologicamente isolados por meio de sucessivas inoculações em Chenopodium quinoa. A análise das seqüências de nucleotídeos, de aminoácidos e os resultados sorológicos revelaram a presença de três espécies distintas de allexivirus GarV-C, GarV-D e Garlic mite-borne filamentous virus (GarMbFV) no Brasil.
\end{abstract}

Termos para indexação: Allium sativum, detecção de vírus, proteínas capsidiais, Dot-ELISA, RT-PCR.

\section{Introduction}

Virus diseases of garlic are usually induced by mixed infections of several viruses belonging to different taxonomic groups, which are known as the garlic viral complex (Van Dijk, 1993). A variable number of potyviruses and carlaviruses have been reported infecting garlic plants, but their identity remains to be elucidated and they probably represent mixtures of well known viruses or their strains (Tsuneyoshi et al., 1998). In addition to the genera Potyvirus and Carlavirus, garlic plants have often been infected with rymoviruses, miteborne filamentous viruses, which are now members of the established genus Allexivirus.

Mite-borne viruses were first reported in 1970 by Razvjakina (Dovas et al., 2001) infecting onions and they were first named onion mosaic virus (OMV). These new viruses were first described by Van Dijk et al. (1991) who partially characterized Onion mite-borne latent virus (OMbLV) and Shallot mite-borne latent virus (SMbLV). Their genome organization differs from carlaviruses and potyviruses by the presence of an ex- 
tra gene (ORF $4=42 \mathrm{~K})$ with unknown function, absent in these two virus genera (Van Regenmortel et al., 2000).

Although the molecular organization of these viruses has been partially elucidated (Van Regenmortel et al., 2000), very little is know about the virus diversity, virus dissemination and crop losses related to these pathogens, occurring alone or in complex as often observed for garlic viruses (Conci et al., 1999).

In Brazil, garlic is largely cultivated in different geographical areas. Typical virus symptoms have been found in all commercial fields. The causal agents detected in different areas were reported as most likely to be a garlic viral complex, comprised by potyviruses and carlaviruses (Dusi, 1995). However, the identity of these pathogens and their relationship with other garlic viruses is still not completely elucidated. Recently in Brazil, potyviruses and carlaviruses naturally infecting garlic plants have been characterized (Fajardo et al., 2001). However, no allexiviruses have been detected.

\section{Material and Methods}

Garlic plants (cvs. Amarante and Caçador) infected with the garlic virus complex, collected from Água Fria (State of Goiás), Gama (Federal District) and São Gonçalo (State of Minas Gerais), were tested by Dot-Elisa (Hammond \& Jordan, 1990) for the detection of allexiviruses using monoclonal antisera specific for GarV-A, GarV-B and GarV-C, a polyclonal antiserum able to detect these three species and GarV-D (Yamashita et al., 1996), and a polyclonal antiserum against GarV-A obtained from IFFIVE/INTA, Argentina. Field collected cloves from symptomatic plants were grown under greenhouse conditions and the apical leaves were harvested 30 days after planting for serological tests.

Based on serological tests, positive samples of each Allexivirus species were first isolated by four successive local lesion passages though Chenopodium quinoa using $0.05 \mathrm{M}$ phosphate buffer, $\mathrm{pH}$ 8.0. For inoculum preparation, the isolates were mechanically inoculated onto virus-free garlic plants (obtained according to Torres et al., 2000), maintained in a greenhouse and monitored weekly for symptoms. Total RNA of infected garlic plants was extracted according to Chomczynsky \& Sacchi (1987).

For PCR, primers were designed (Figure 1A) from specific sequences out of the CP gene (ORF 5) (Figure 1B) of GarV-A (AB10300), GarV-B (GVU89243), GarV-C (AB10302) and GarV-D (AB10303) strains available in the literature or based on databank sequences (Yamashita et al., 1996). First strand cDNA synthesis was performed employing 600 to $830 \mathrm{ng}$ of total RNA using primers GarV-A2, GarV-B2, GarV-C2 e and GarV-D2 (Figure 1A), and using the protocol Access RT-PCR System from Promega, according to the manufacturer's instructions.

For PCR, $10 \mu \mathrm{L}$ of the RT mix was added to a $40 \mu \mathrm{L}$ polymerase reaction mixture containing $20 \mathrm{mM}$ Tris- $\mathrm{HCl}$ (pH 8.4), $50 \mathrm{mM} \mathrm{KCl}, 1.5 \mathrm{mM} \mathrm{MgCl} 2,200 \mu \mathrm{M}$ each $\mathrm{dNTP}, 2.5 \mathrm{U}$ of Taq DNA polymerase and $1 \mathrm{ng} / \mu \mathrm{L}$ of the primer combinations specific for each virus (Figure 1A). PCR steps were 40 cycles $\left(94^{\circ} \mathrm{C} / 30 \mathrm{~s}\right.$, $53^{\circ} \mathrm{C} / 30 \mathrm{~s}$ and $68^{\circ} \mathrm{C} / 90 \mathrm{~s}$ ). $\mathrm{PCR}$ products were analyzed by electrophoresis on $1 \%$ agarose gel.

Amplified PCR products were cloned in the pGEM-T vector. Both strands of recombinant clones from at least five independent RT-PCR reactions were sequenced in an automatic MEGA BASE 1000 sequencer and ABI 377. Sequences were compiled and analyzed using algorithms of the GCG package University of Wisconsin (Devereux et al., 1984). GeneBank searches were performed using BLAST (Altschul et al., 1990).

\section{Results and Discussion}

When garlic plants of cultivar Amarante were tested by Dot-Elisa, serological samples were positive for the four distinct viruses. However, plants of cultivar Caçador reacted positively only with the antiserum against GarV-B.

DNA fragments of the expected sizes (approximately 800 bp) comprising the complete $\mathrm{CP}$ gene of GarV-A, GarV-C and GarV-D were successfully amplified.

The GarV-A fragment revealed to be higher homologous than the previously described Garlic miteborne filamentous virus (GarMbFV) Argentinean (96.6\% amino acids homology) and less with the GarV-A Japanese (89\% amino acids homology). The fragment representing the $\mathrm{CP}$ gene of $\mathrm{GarMbFV}_{\mathrm{BR}}$ (Brazilian isolate) contained 762 nucleotides, with a predicted $M_{r}$ of about $28 \mathrm{kDa}$ (Figure 2A). The fragment of GarV$\mathrm{C}_{\mathrm{BR}} \mathrm{CP}$ gene contained 781 nucleotides encoding a protein of $\mathrm{M}_{\mathrm{r}}$ of $29 \mathrm{kDa}$ (Figure 2B). The amplified fragment containing the coat protein of GarV- $\mathrm{D}_{\mathrm{BR}}$ has 753 nucleotides long, potentially coding for a protein of 251 amino acids residues with a predicted $\mathrm{M}_{\mathrm{r}}$ of about $28 \mathrm{kDa}$ (Figure 2C). No GarV-B fragments were 
amplified using the specific primers for this virus, although, serological data indicated the presence of a related virus species in field samples.

A search in the Genetic Bank database of NCBI revealed that the deduced amino acid sequences of $\mathrm{GarMbFV}_{\mathrm{BR}}$, GarV-C $\mathrm{C}_{\mathrm{BR}}$ and GarV-D $\mathrm{D}_{\mathrm{BR}}$ clones had high homology with deduced amino acid sequences of $\mathrm{CP}$ protein genes of virus species deposited in database NCBI (Table 1). For the last two few amino acid changes, 14 for the GarV- $\mathrm{C}_{\mathrm{BR}}$ and 10 for the GarV$\mathrm{D}_{\mathrm{BR}}$ could be detected compared to the original sequences of the Japanese strains.

Following the Brazilian Governmental regulations for the report of new pathogens in Brazil (PI MA/ME n 290/96), the occurrence of the three virus species first detected in this work was informed to Ministry of Agriculture before publication. The identification of virus infections in garlic plants have been based on serology, host range and sequence data of the coat protein gene (Tsuneyoshi et al., 1998).

Results obtained by coat protein sequence demonstrated that $\mathrm{GarMbFV}_{\mathrm{BR}}$ represents a distinct Allexivirus species, since identity of coat protein sequences is less than $90 \%$ compared to homology with
GarV-A Japanese. Also the longer coat protein ORF (762 nt) of GarMbFV from Brazil and Argentina compared to the GarV-A Japanese (755 nt) reinforced this result. This seems also true for the Leak yellow strip virus (LYSV, Potyvirus).

A Brazilian LYSV isolate infecting garlic plants showed a significantly lower amino acid homology (average of $88.6 \%$ ) with isolates from distinct geographical areas (Fajardo et al., 2001). For tospoviruses, a Brazilian isolate of Iris yellow spot virus (IYSV), found in naturally infected onion fields, showed $10 \%$ diversity in the nucleocapsid protein gene with the IYSV type species described in The Netherlands. This identity values found for the nucleocapsid gene was at the borderline to be considered as new species in the genus (Pozzer et al., 1999).

The sequence of the coat protein gene has been used as an efficient tool to define Potyvirus species (Shukla et al., 1994). For GarV-C and GarV-D, although sequence alignment showed high homology values, allowing a precise determination of the garlic virus species, the variation observed can be explained by natural strain variation among virus isolates. Following the data observed for potyviruses (Tsuneyoshi et al., 1998),

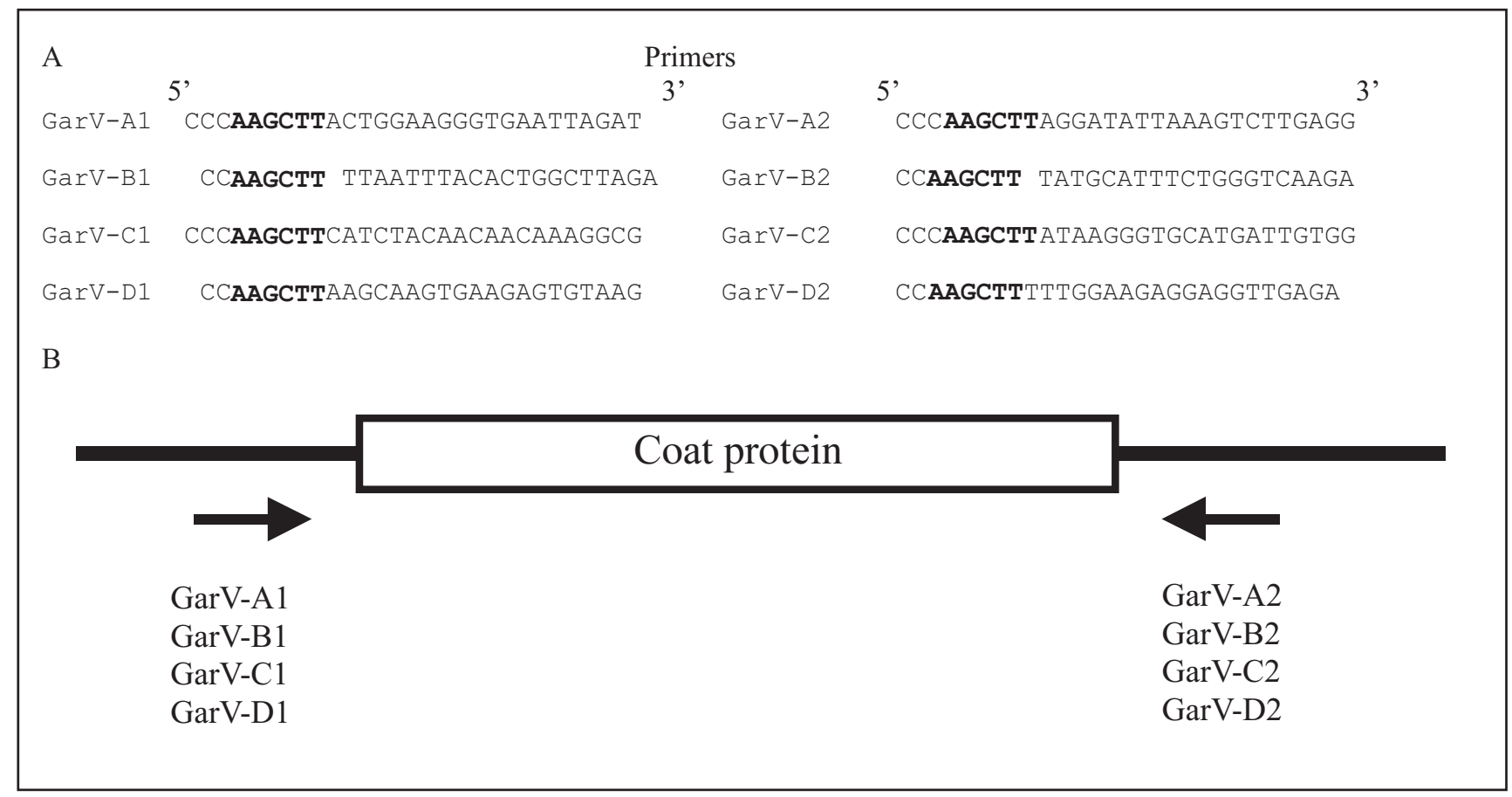

Figure 1. A) Primer sequences pairs used for the amplification of the coat protein genes of Allexivirus species found in Brazil (bold type letters are Hind III restriction sites ). B) Representation of primer locations out of the coat protein gene. 


\section{$A$}

\begin{tabular}{|c|c|c|c|}
\hline \multirow{2}{*}{$\begin{array}{l}\text { Brazil } \\
\text { Argentine }\end{array}$} & 1 & \multirow{2}{*}{ 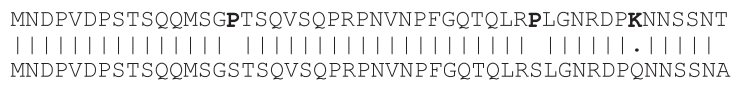 } & \multirow{2}{*}{$\begin{array}{l}50 \\
50\end{array}$} \\
\hline & 1 & & \\
\hline & 51 & 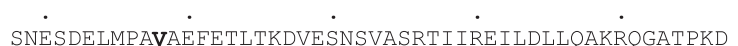 & 100 \\
\hline & 31 & 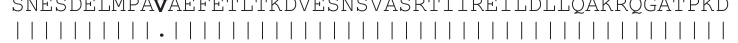 & 100 \\
\hline & 51 & SNESDELMPALAEFETLTKDVESNSVASRTI IRE I LDLLQAKRQGATPKD & 100 \\
\hline & 101 & LFS்LWTCYHNGSSRFVTLTTDAPCGMAHSELKDIVENYCTLR்EFCGFY & 150 \\
\hline & & $1 \mid 11111111111111111111111111111111: 11.1111111111111$ & \\
\hline & 101 & LLSLAWTCYHNGSSRFVTLTTDAPCGMAHSELKDVVEDYCTLRQFCGFYA & 150 \\
\hline & 151 & KACYVTGKQQNKPPANWSRKGYQEDSKFAAFDFFNAVLSDSFPNPPGGMM & 200 \\
\hline & 151 & KACYVTGKQQNKPPANWSRKGYQEDSKFAAFDFFNAVLSDSSPNPPGGMR & 200 \\
\hline & 201 & $\begin{array}{l}\text { FKPTDAE ILAHSLNAKMS IVESRRATNMVSTRADLLAQQQI HEQPKPPMI } \\
\text { (1) }\end{array}$ & 250 \\
\hline & 201 & FKPTDAEILAHSMNAKMS IVESRRATNMVSTRADLLAQQQI HEQPKPPMI & 250 \\
\hline & & 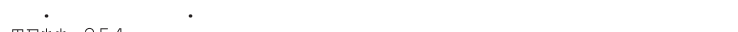 & \\
\hline & 251 & $\begin{array}{l}\mathrm{TF}^{\star \star} \star 254 \\
||||\end{array}$ & \\
\hline & 251 & $\mathrm{TF}^{\star \star} 254$ & \\
\hline & & & \\
\hline Brazil & 1 & 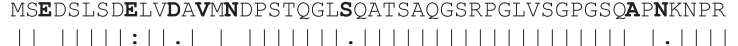 & 50 \\
\hline Japan & 1 & MSGDSLSDDLVNAAMTDPSTQGLNQATSAQGSRPGLVSGPGSQTPSKNPR & 50 \\
\hline & 51 & 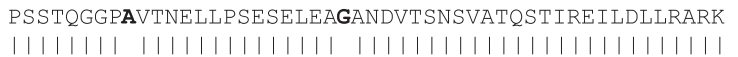 & 100 \\
\hline & 51 & PSSTQGGPTVTNELLPSESELEAVANDVTSNSVATQSTIREILDLLRARK & 100 \\
\hline & 101 & PNASPKDLFSLAWACYHNGSSRYTNLATDAPCGMSHAELKDLVEEFCTLR & 150 \\
\hline & 101 & 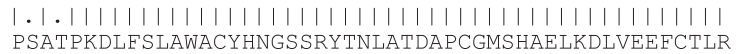 & 150 \\
\hline & & & \\
\hline & 151 & QFCGFYAKTCYVTGRQQNKPPANWARKGFQDESKFAAFDFFNAMSSDSAP & 200 \\
\hline & 151 & $\begin{array}{l}||||||||||||||||||||||||||||||||||||||||||=|||||| \mid \\
\text { QFCGFYAKTCYVTGRQQNKLPANWARKGEQDESKFAAFDFFAVSSDSAP }\end{array}$ & 200 \\
\hline & & & \\
\hline & 201 & 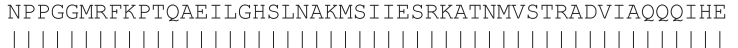 & 250 \\
\hline & 201 & NPPGGMRFKPTQAEI LGHSLNAKMS I IESRKATNMVSTRADVIAQQQI HE & 250 \\
\hline & 251 & PPKPLMLTF* 260 & \\
\hline & & $\begin{array}{l}\text { IIIIIIIIIII } \\
\text { PPKPIMITF* } 260\end{array}$ & \\
\hline & 201 & PPKPLMLTF* 260 & \\
\hline Japan & 1 & 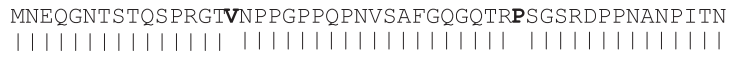 & 50 \\
\hline Brazil & 1 & MNEQGNTSTQSPRGTANPPGPPQPNVSAFGQGQTRASGSRDPPNANPITN & 50 \\
\hline & 51 & EQDELMPAVTEFENLANDVESNSLASRATIRDILDMLQATRQGATPKDLF & 100 \\
\hline & & $1111111111111111111111: 11111111111111111: 111111111$ & \\
\hline & 51 & EQDGLMPAVIEFENLANDVESNSIASRATIRDI LDMLQATKPGATPKDLF & 100 \\
\hline & 101 & SLAWTCYHNGSSRFVTLSTKAPCGMPLSELKDLVENFCTLRQFCGFYAKA & 150 \\
\hline & 101 & SLAWTCYHNGSSRFVTLSTKAPCGMPHSELKDLVENFCTLRQFCGVYAKA & 150 \\
\hline & 151 & CYVTGKQQKKPPASWSRKGYQDDAKFAGFDFFNAVLSDFSPAPPGGMRFK & 200 \\
\hline & 151 & CYVTGKQQKKPPASWSRKGYQDDAKFAGFDFFNAVLSDFSPAPPGGMRFK & 200 \\
\hline & 201 & PTDAEILAHSMNAKMSIVESRRSSNMVSTRADLLAQQQI HEQPKPPMITF & 250 \\
\hline & & 11111111111111111111111.1111111111111111111111111111 & \\
\hline & 201 & PTDAE I LAHSMNAKMS IVESRRASNMVSTRADLLAQQQIHEQPKPPMITF & 250 \\
\hline & 251 & $\star 251$ & \\
\hline & $\begin{array}{r}1 \\
251\end{array}$ & * 251 & \\
\hline
\end{tabular}

Figure 2. Amino acid alignment of the coat protein genes of Allexivirus species characterized in Brazil. A) Garlic mite-borne filamentous virus $\left(\mathrm{GarMbFV}_{\mathrm{BR}}\right)$ and GarMbFV Argentinean (accession number X98991). B) Garlic virus $C$ (GarV- $\mathrm{C}_{\mathrm{BR}}$ ) and GarV-C Japanese (accession number AB010302). C) Garlic virus D (GarV- $\mathrm{D}_{\mathrm{BR}}$ ) and GarV-D Japanese (accession number AB010303). Amino acids are numbered from the amino terminus of the coat proteins. The asterisks indicate the stop codons. Bold type letters represent amino acids differences between species. 
no correlation between geographical localization and sequence homology in the coat protein genes of distinct isolates of allexiviruses has been detected. For the isolate $\mathrm{GarMbFV}_{\mathrm{BR}}$ serologically related to GarV-A, this seems not to be the case, as it showed a significantly lower amino acid homology with homologous isolates from distinct geographical areas of Japan and Korea. The higher identity with the Argentinean GarMbFV suggested that selection pressures, such as environmental conditions, alternative hosts, vector efficiency, may therefore be involved in the generation of these genetic variations, implying an adaptation of this virus to distinct ecological niches.

How garlic viruses have been introduced and adapted to Brazil remains obscure. However, trading of garlic bulbs imported from Europe, Asia and Argentina, may have taken an important role in virus introduction in the country. In 1991, Van Dijk et al. reported the presence of Allexivirus on onion originated from China and Spain, exporter countries to Brazil. Part of the bulbs imported for consumption is often used as seeds to establish new crops, being probably responsible for the introduction of new diseases in the country (Agrianual, 2001).

Similar to the Potyvirus genus (Koch \& Salomon, 1994), serology is not a very good tool for virus species differentiation among Allexivirus, as serological cross reactions often cause misinterpretation of results, as observed in this work for GarV-A and GarV-B. Cross reaction due to conserved epitopes on coat proteins are often pointed as responsible for serological relationships among plants viruses (Almeida \& Lima, 2001). Although serology can be used for Allexivirus detection, it is not suitable for Allexivirus taxonomy. This observation supports the application and need of molecular techniques for characterization of viruses in the garlic virus complex,

Table 1. Percent of amino acid sequence of Brazilian allexiviruses Garlic mite-borne filamentous virus $\left(\mathrm{GarMbFV}_{\mathrm{BR}}\right)$, Garlic virus $C\left(\mathrm{GarV}-\mathrm{C}_{\mathrm{BR}}\right)$, Garlic virus D (GarV$\mathrm{D}_{\mathrm{BR}}$ ) with related allexiviruses characterized in Japan and Argentine.

\begin{tabular}{lccccc}
\hline \multirow{2}{*}{$\begin{array}{c}\text { Brazilian } \\
\text { isolates }\end{array}$} & \multicolumn{5}{c}{ Foreign isolates } \\
\cline { 2 - 6 } & GarV-A $^{(1)}$ & GarV-B $^{(1)}$ & GarV-C $^{(1)}$ & GarV-D $^{(1)}$ & GarMbFV $^{(2)}$ \\
\hline GarMbFV $_{\text {BR }}$ & 89 & 64 & 65 & 75.0 & 96.6 \\
GarV-C $_{\text {BR }}$ & 63 & 70 & 95 & 65.0 & 64.0 \\
GarV-D $_{\text {BR }}$ & 76 & 65 & 64 & 96.8 & 75.0 \\
\hline
\end{tabular}

(1)Japanese isolates. ${ }^{(2)}$ Argentinean isolates. as demonstrated by other reports (Nagakubo et al., 1994; Tsuneyoshi et al., 1998; Fajardo et al., 2001).

In addition to the RT-PCR, the analysis of clones obtained from the virus genomes can also be used to determine the variability of distinct viruses in the garlic virus complex (Tsuneyoshi \& Sumi, 1996). Virus identity is important for the study of virus epidemiology and to support breeding programs for the development of garlic cultivars resistant to virus infection.

\section{Conclusion}

This report presents the nucleotide sequences of the $\mathrm{CP}$ genes of three distinct field isolates of allexiviruses, which represents an important step for the establishment of a free garlic virus seed program in the country.

\section{References}

AGRIANUAL 2002: anuário da agricultura brasileira. São Paulo: FNP Consultoria e Comércio, 2001. 536p.

ALMEIDA, A.M.R.; LIMA, J.A.A. Técnicas sorológicas aplicadas à fitovirologia. In: ALMEIDA, A.M.R.; LIMA, J.A.A. (Ed.). Princípios e técnicas de diagnose aplicados em fitovirologia. Londrina: Embrapa Soja; Sociedade Brasileira de Fitopatologia, 2001. 185p.

ALTSCHUL, S.F.; GISH, W.; MILLER, W.; MYERS, E.W.; LIPMAN, D.J. Basic local alignment search tool. Journal of Molecular Biology, v.215, p.403-410, 1990.

CHOMCZYNSKI, P.; SACCHI, N. Single-step method of RNA isolation by acid guanidinium thiocyanate-phenol-chloroform extraction. Analytical Biochemistry, v.162, p.156-159, 1987.

CONCI, V.C.; CANAVELLI, A.E.; LUNELLO, P.A.; CAFRUNE, E.E. Mosaico del ajo. In: PROJECTO de investigaciones en fitovirologia. Buenos Aires: Instituto de Fitopatologia y Fisiologia Vegetal; Instituto Nacional de Tecnologia Agropecuária, 1999. p.1-6.

DEVEREUX, J.; HAEBERLI, P.; SMITHIES, O. A comprehensive set of sequence analysis programs for the VAX. Nucleic Acids Research, v.12, p.387-395, 1984.

DOVAS, C.J.; HATZILOUKAS, E.; SALOMON, R.; BARG, E.; SHIBOLETH, Y.; KATIS, N.I. Incidence of viruses infecting Allium spp. in Greece. European Journal of Plant Pathology, v.107, p.677-684, 2001.

DUSI, A.N. Doenças causadas por vírus em alho. Informe Agropecuário, v.17, p.19-21, 1995.

FAJARDO, T.V.M.; NISHIJIMA, M.; BUSO, J.A.; TORRES, A.C.; ÁVILA, A.C.; RESENDE, R.O. Garlic viral complex: identification of potyviruses and carlavirus in central Brazil. Fitopatologia Brasileira, v.26, p.619-626, 2001.

HAMMOND, J.; JORDAN, R.L. Dot blots (viruses) and colony screening. In: HAMPTON, R.; BALL, E.; De BOER, S. Serological methods for detection and identification of viral and bacterial plant pathogens: a laboratory manual. St. Paul: APS Press, 1990. p.237-248. 
KOCH, M.; SALOMON, R. Serological detection of onion yellow dwarf virus in garlic. Plant Disease, v.78, p.785-788, 1994.

NAGAKUBO, T.; KUBO, M.; OEDA, K. Nucleotide sequences of the 3' regions of two major viruses from mosaic-diseased garlic: molecular evidence of mixed infection by a Potyvirus and a Carlavirus. Phytopathology, v.84, p.640-645, 1994.

POZZER, L.; BEZERRA, I.C.; KORMELINK, R.; PRINS, M.; PETERS, D.; RESENDE, R.O.; ÁVILA, A.C. Characterization of a tospovirus isolate of Iris yellow spot virus associated with a disease in onion fields in Brazil. Plant Disease, v.83, p.345-350, 1999.

SHUKLA, D.D.; WARD, C.W.; BRUNT, A.A. The Potyviridae. Wallingford: CAB International, 1994. 516p.

TORRES, A.C.; FAJARDO, T.V.M.; DUSI, A.N.; RESENDE, R.O.; BUSO, J.A. Shoot tip culture and thermoterapy for recovering virusfree plants of garlic. Horticultura Brasileira, v.18, p.192-194, 2000.

TSUNEYOSHI, T.; MATSUMI, T.; NATSUAKI, K.T.; SUMI, S. Nucleotide sequence analysis of virus isolates indicates the presence of three Potyvirus species in Allium plants. Archives of Virology, v.143, p.97-113, 1998.
TSUNEYOSHI, T.; SUMI, S. Differentiation among garlic viruses in mixed infections based on RT-PCR procedures and direct tissue blotting immunoassays. Phytopathology, v.86, p.253-259, 1996.

VAN DIJK, P. Survey and characterization of Potyviruses and their strains of Allium species. Netherlands Journal of Plant Pathology, v.99, p.1-48, 1993.

VAN DIJK, P.; VERBEEK, M.; BOS, L. Mite-borne virus isolates from cultivated Allium species, and their classification into two new rymoviruses in the family Potyviridae. Netherlands Journal of Plant Pathology, v.97, p.381-399, 1991.

VAN REGENMORTEL, M.H.V.; FAUQUET, C.M.; BISHOP, D.H.L.; CARSTENS, E.B.; ESTES, M.K.; LEMON, S.M.; MANILOFF, J.; MAYO, M.A.; McGEOCH, D.J.; PRINGLE, C.R.; WICKNER, R.B. (Ed.). Virus taxonomy: the seventh report of the International Committee on Taxonomy of Viruses. San Diego: Academic Press, 2000. 1162p.

YAMASHITA, K.; SAKAI, J.; HANADA, K. Characterization of a new virus from garlic (Allium sativum L.), garlic mite-borne mosaic virus. Annals of the Phytopathological Society of Japan, v.62, p.483-489, 1996.

$\overline{\text { Received on February 11, } 2004 \text { and accepted on June 9, } 2004}$ 